\title{
Examination of the Skills of Secondary School Students to Draw and Analysis Graphs in Three Basic Types of Graphs
}

\author{
Remzi NAMAL' \\ Provincial Directorate of National Education, Düzce, TURKEY
}

${ }^{1}$ Dr.; Provincial Directorate of National Education, Düzce, TURKEY. namal2506 [at] gmail.com. ORCID: 0000-0002-5593-691X

\begin{abstract}
The aim of this research is to examine the skills of secondary school students to draw and analysis charts using the bar chart, line chart and pie chart, known as the three basic chart types in social studies teaching. The research was applied in the experimental design in the single group post-test model, based on the application of the independent variable to a single group and the observation of its effect on the dependent variable. The secondary school was attended by a total of 35 students who were studying in the seventh grade. A teaching model was applied to the research group, which included activities prepared in accordance with achievements based on the skill to draw and interpret charts during the research period. The graph drawing and analysis skill checklist (GDAS-CL) scale developed by the researcher was used to collect data for the study. Descriptive statistical methods, t-test and variance analysis (ANOVA) were used in the analysis of the data obtained within the scope of the research. Data obtained from research in graph plotting and analysis of scores in all three chart types showed significant differences in the skill in graphing, graphing, and analysis skill points depending on the chart type of the bar chart showed significant differences in favor observed. Skill to draw and interpret charts according to their total skill scores, it was observed that the type of chart that students were most successful at drawing and interpreting was a bar chart, and the type of chart that they were most difficult to draw was a line chart.
\end{abstract}

\section{Keywords}

Social Studies, Drawing Graphics, Analysis Graphics, Teaching Skill 
Social Studies is a curriculum that combines the knowledge and methods it receives from the social and humanities in order to educate effective citizens who can make decisions based on knowledge and solve problems in almost every changing country and world conditions (Öztürk, 2012, p. 4). Courses with Social Studies content are currently taught at different grade levels in schools in various countries around the world. The Social Studies course, which is based on the first years of the Republic in Turkey and took this name with the 1968 curriculum, has undergone various changes in terms of the curriculum over the years. Recently NCSS (National Council for the social Studies) Social Studies developed by the basic principles of the constructivist approach on the basis of the new social studies curriculum that is based on were started in 2005, and finally, the principles of this curriculum in 2018 has been revised with the aim of breeding a creative and active individuals (Açıkalın, 2017, p. 1; MoNE, 2018).

In the Social Studies course, where verbal content takes up a wide place, various teaching materials that contribute to learning are used in order to make learning permanent and to obtain targeted attainments. Which material is used for what purpose and how it is used depends on the content of the subject. However, due to the content that the social studies course has, it requires a large number of different visual materials within the teaching processes. Including, motivating, adding vitality to the teaching environment, contributing to catchy and addressing individual differences is notable for demonstrating the importance of visual materials for Social Studies (Yazıcı, 2006; Ulusoy \& Gülüm, 2009). Among these materials, one of the most widely used are the chart, which are located under the broad perspective of visuals.

Charts are the presentation of information or numerical data in shape (Arıkan, 2003, p. 2; Wong \& Gerber, 2008). Although there are specific types that apply to different branches of science, the best-known chart types are line chart, pie chart, and bar chart. There are many advantages that charts provide, which are very useful in presenting information and making sense of complex data. Being remarkable, relying on spatial intelligence instead of linguistic intelligence, allowing you to see data directly and instantly, making it easier to compare and identify trends, depicting the relationship between variables, animating the presentation, interpreting, modeling and transforming are some of these advantages that charts provide (Anscombe, 1973; Leivian, 1980; Korol, 1986; Duplass, 1996; Beattie \& Jones, 2002; Kwon, 2002).

In Social Studies teaching, different types of charts are used depending on the content of the learning area (economy, population, climate). However, the most commonly used chart types according to student level are pie charts, bar charts and line charts (Parker, 2001, p. 171). Charts are very important teaching materials in terms of being easy to understand in Social Studies teaching, including abstract concepts, allowing comparison between data and ensuring permanence in learning. It includes the skill to draw and interpret charts in skill teaching, which is defined as 
Namal, R. (2021). Examination of the skills of secondary school students to draw and analysis graphs..

the activities that students can do or perform in relation to the competencies (Namal, 2019/a, p. 529).

Graph literacy, which is defined as the skill to read, interpret and draw basic types of charts and continues to exist throughout life, includes the skill to draw and interpret charts. In order for an individual to be graph literacy, it is necessary to have the skill to draw and interpret chart (Fry, 1981; Sofo, 1985; Davison, 2013, p. 15). Chart and analysis in the Social Studies curriculum in Turkey in 2005, while in 2018 the skill of sub place perception as a skill that students need to learn basic skills in social studies education program updated 27 as one of the skills identified as 'table, chart and diagram drawing and interpreting' as the skill of are included (MoNE, 2005; MoNE, 2018).

The aim of main attainmented the skill to draw chart in Social Studies teaching is to clearly and clearly show complex and excessive amounts of presented data in a limited place and to contribute to permanent learning by helping to include abstract concepts. For this reason, the chart to be drawn must be appropriate to the student level and subject content. Chart drawing tools (millimeter paper, jib, angle meter, etc.) it is necessary to introduce and draw according to the stages of chart drawing (determining the most appropriate chart type for the data presented, determining the axes of the chart and scaling, placing points and completing the drawing). A good chart drawing is necessary if the shape of the chart being drawn is clear, has a title, has a scale in the appropriate place, and the source on which the data is based is clearly seen. (Savage \& Armstrong, 1996, p. 350; Dilek, İşçi \& Göktaş, 2010, p. 4; Namal, 2019/b, p. 88-89).

Skill to interpret charts is the meaningful reading of information indicated by charts. As a basis for chart analysis, the method that is followed involves sorting from simple to complex. This ranking -in general-occurs as reading data in a chart (answering questions where the answer is clear), reading between data (combining and interpreting information in a chart), and reading over data (forecasting, inference). In Social Studies teaching, the basic requirement for students to fully acquire the skill to interpret chart is the need to adequately recognize the concept of 'chart' (Curcio, 1987; Mannhood, Biemer \& Lowe, 1991; Wainer, 1992; Friel \& Bright, 1996; MoNE, 2005).

The importance of the skill to draw and interpret chart is better when considering both the fact that it is a lifelong skill field and the size of the field it occupies in teaching Social Studies. The main problems experienced by students related to the skill to draw and interpret chart in teaching Social Studies in Turkey are that they have difficulty understanding and analysing information. This difficulty is manifested in International Educational Research as well as in the country. It shows that students participating in international educational assessments from Turkey achieve very low scores in questions related to graph literacy, and that studies aimed at solving this problem need to be put forward. (Oruç \& Akgün, 2010; Anıl, 
Özkan \& Demir, 2012; Martin, et al., 2012; Güler, 2013; Taş, et al., 2016; Namal, 2019/b, p. 7).

The aim of this research is to examine the skill of secondary school students to draw and interpret charts using the bar chart, line chart and pie chart, known as the three basic chart types in social studies teaching. The research aims to find answers to the following questions:

1. Are the chart drawing skill scores of experimental group students different according to the chart type variable?

2. Do the chart analysis skill scores of experimental group students differ according to the chart type variable?

3. Do the skill scores of experimental group students to draw and analysis charts differ according to the chart type variable?

4. Are the skill scores of experimental group students to draw chart and analysis differ according to the variables of drawing and analysis?

\section{Methodology}

\section{Research Model}

The research was designed in the one group post-test experimental pattern model, based on the application of the independent variable to an one group and the observation of its effect on the dependent variable (Karasar, 2004, p. 96). The model of the research is shown in Table 1.

Table 1

One Group Post-Test Model

\begin{tabular}{ccc}
\hline Group & Process & Post-test \\
\hline $\mathrm{D}_{1}$ & $\mathrm{X}$ & Ö$_{1,2}$ \\
\hline
\end{tabular}

\section{Working Group}

A total of 35 students who are studying at a state secondary school in Düzce province in the 2019-2020 academic year and who are selected by intact appointment constitute the working group of the research. Table 2 shows the data of the research working group.

Table 2

Working Group

\begin{tabular}{lcc}
\hline Group & Grade & n \\
\hline Experimental & 7 & 35 \\
\hline
\end{tabular}

\section{Data Collection}

The chart drawing and analysis skills checklist (GDAS-CL) scale developed by Namal (2019) was used to collect data for the study. The GDAS-CL scale consists of a total of 16 items, taking expert opinions according to the level of students at the secondary school level, depending on the skill stages of drawing and analysis charts. 
Namal, R. (2021). Examination of the skills of secondary school students to draw and analysis graphs..

The first 10 items of the GDAS-CL scale aim to measure the skill to draw chart, and the last 6 items aim to measure the skill to analysis charts.

The scope validity of the GDAS-CL scale was established using the Lawshe (1975) technique. According to expert opinions in Lawshe (1975) technique, scale substances are subject to a triple assessment as 'necessary, useful/inadequate, unnecessary'. Substances that more than half of experts respond to 'necessary' are included in the form as final substances without being removed from the form, as they provide the required scope validity rate. It is expected to have minimum values of $\alpha=0.05$, tabulated by Veneziano \& Hooper (1997), in order to test the statistical significance of the substances that provide the required scope validity rate and will be included in the final form. The table contains the minimum values of the scope validity rate according to the number of experts who express their opinion on the form. These values also constitute the scope validity criterion of the scale form. In order for the scope validity of the scale to be statistically significant, the scope validity index obtained is determined according to the averages of the scope validity rates. The scope validity index must be greater than the scope validity criterion. (Yurdugül, 2005). The scope validity criterion of the GDAS-CL scale was found to be 0.62 at the significance level $\alpha=0.05$ and the scope validity index was 0.94 . Since the scope validity index has a value greater than the scope validity criterion, the scope validity of the GDAS-CL scale is statistically significant. In the validity and reliability analyses of the GDAS-CL scale, the total variance of the scale was found to be $72,507 \%$ and the cronbach alpha reliability coefficient was 0.963 .

\section{Process}

The application process of the research was carried out in accordance with the learned program to cover four weeks of ten course hours and three achievements. In the activity-based teaching process, the method of showing and making was used. Each week is divided from three course hours into two hours and one hour of instruction. During the course hours for applications, the first course followed the polling of preliminary information about the chart type, the transfer of general information about the chart type, the drawing and analysis of the chart type. In the second course, activity applications related to the skill to draw and interpret chart were carried out. At the end of the applications, the activities were evaluated using the GDAS-CL scale and statistical evaluation was made.

\section{Data Analysis}

Descriptive statistical methods, t-test and variance analysis (ANOVA) were used in the analysis of the data obtained from the study.

\section{Findings}

\section{Findings about the First Sub-Problem}

In the first sub-problem of the study, it was investigated whether the chart drawing skill scores of the experimental group students differed according to the 
chart type variable. The data obtained were examined by analysis of variance (ANOVA). The findings of the first sub-problem of the study are shown in Table 3.

Table 3

Comparison of Chart Drawing Skill Scores by Chart Types

\begin{tabular}{lccccccccc}
\hline Drawing Skill & $\mathrm{n}$ & $\overline{\mathbf{x}}$ & $\mathrm{Ss}$ & Variance & $\begin{array}{l}\text { Sum } \\
\text { Squares }\end{array}$ & ${ }^{\text {of }} \mathrm{Sd}$ & $\begin{array}{l}\text { Squares } \\
\text { Average }\end{array}$ & $\mathrm{F}$ \\
\hline Line Chart & 35 & 13,60 & 1,31 & Intergroups & 115,886 & 2 & 57,943 & 24,388 & 0,000 \\
\hline Pie Chart & 35 & 14,97 & 1,64 & Ingroups & 242,343 & 102 & 2,376 & & \\
\hline Bar Chart & 35 & 16,17 & 1,65 & Total & 358,229 & 104 & & &
\end{tabular}

When the results in Table 3 were evaluated, the type of chart in which the experimental group students were most successful in drawing skills was bar chart $=16.17$, and the bar chart was followed by pie chart $=14.97$ and line chart $=13.60$, respectively. It was also found that there were significant differences between drawing skill scores $(\mathrm{F}=24,388 ; \mathrm{p}<0.05)$. A Tukey HSD multiple comparison test (post hoc) was performed to determine which types of charts have significant differences. The findings are shown in Table 4.

Table 4

Multiple Comparison (Post-Hoc) Findings on Comparing Chart Drawing Skill Scores by Chart Type

\begin{tabular}{cccc}
\hline (A) Chart Type & (B) Chart Type & Difference between averages (A-B) & $\mathrm{p}$ \\
\hline \multirow{2}{*}{ Line Chart } & Pie Chart & $-1,37$ & 0,001 \\
\cline { 2 - 4 } & Bar Chart & $-2,57$ & 0,000 \\
\hline \multirow{2}{*}{ Pie Chart } & Line Chart & 1,37 & 0,001 \\
\cline { 2 - 4 } & Bar Chart & $-1,20$ & 0,004 \\
\hline \multirow{2}{*}{ Bar Chart } & Line Chart & 2,57 & 0,000 \\
\cline { 2 - 4 } & Pie Chart & 1,20 & 0,004 \\
\hline
\end{tabular}

According to the findings in Table 4, skill scores between all chart types differ significantly from each other. Students in the experimental group are significantly more successful at drawing a bar chart than at drawing a pie chart and a line chart. They are also significantly more successful at drawing a pie chart than at drawing a line chart. Therefore, students are significantly more unsuccessful in drawing a line chart than in drawing both a pie and a bar chart. Figure 1 shows chart drawing skill scores. 
Namal, R. (2021). Examination of the skills of secondary school students to draw and analysis graphs..

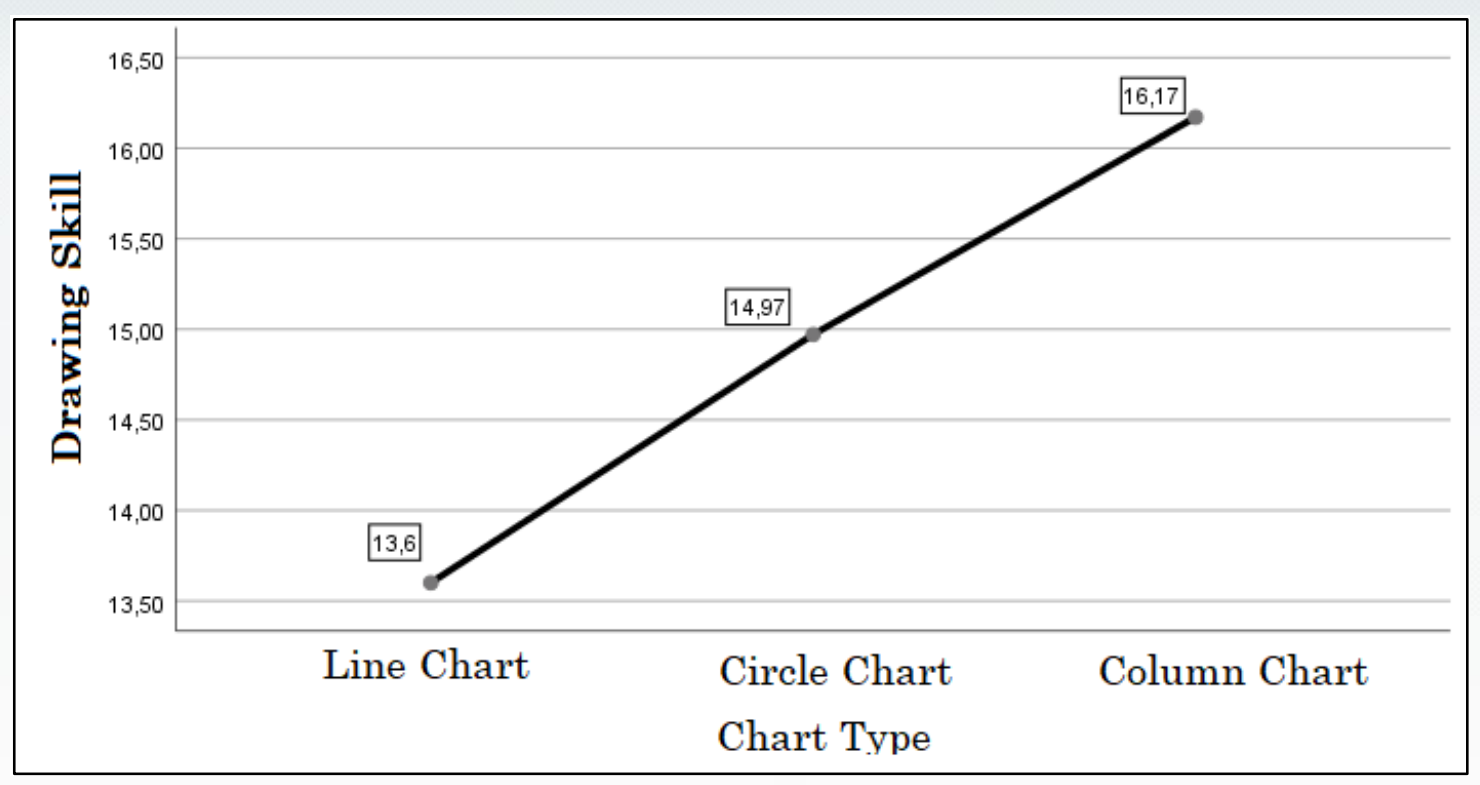

Figure 1. Comparison of chart drawing skill scores by chart type

\section{Findings about the Second Sub-Problem}

In the second sub-problem of the study, it is investigated whether the skill of experimental group students to analysis charts differs according to the chart type variable. The data obtained on the second sub-problem were examined by analysis of variance (ANOVA). The findings are shown in Table 5.

Table 5

Comparison of Chart Drawing Skill Scores by Chart Types

\begin{tabular}{lccccccccc}
\hline Analysis Skill & $\mathrm{n}$ & $\overline{\mathbf{x}}$ & $\mathrm{Ss}$ & Variance & $\begin{array}{l}\text { Sum } \\
\text { Squares }\end{array}$ & ${ }^{\text {of }} \mathrm{Sd}$ & $\begin{array}{l}\text { Squares } \\
\text { Average }\end{array}$ & $\mathrm{F}$ \\
\hline Line Chart & 35 & 7,11 & 1,41 & Intergroups & 50,057 & 2 & 25,029 & 11,920 & 0,000 \\
\hline Pie Chart & 35 & 8,49 & 1,42 & Ingroups & 214,171 & 102 & 2,100 & & \\
\hline Bar Chart & 35 & 8,66 & 1,51 & Total & 264,229 & 104 & & &
\end{tabular}

According to the results in Table 5, the experimental group was the most successful in interpreting the chart type of the students bar chart $=8.66$ and the bar chart was followed by pie chart $=8.49$ and line chart $=7.11$, respectively. It was also found that there were significant differences between chart analysis skill scores $(\mathrm{F}=11,920 ; \mathrm{p}<0.05)$. A Tukey HSD multiple comparison test (post hoc) was performed to determine which types of charts have significant differences. The findings are shown in Table 6. 
Table 6

Multiple Comparison (Post Hoc) Findings on Comparing Chart Analysis Skill Scores by Chart Type

\begin{tabular}{llll}
\hline (A) Chart Type & (B) Chart Type & Difference between averages (A-B) & $p$ \\
\hline \multirow{2}{*}{ Line Chart } & Pie Chart & $-1,37$ & 0,000 \\
\cline { 2 - 4 } & Bar Chart & $-1,54$ & 0,000 \\
\hline \multirow{2}{*}{ Pie Chart } & Line Chart & 1,37 & 0,000 \\
\cline { 2 - 4 } & Bar Chart & $-0,17$ & 0,874 \\
\hline \multirow{2}{*}{ Bar Chart } & Line Chart & 1,54 & 0,000 \\
\cline { 2 - 4 } & Pie Chart & 0,17 & 0,874 \\
\hline
\end{tabular}

According to the findings in Table 6, the chart analysis skill scores between the bar chart and the line chart and the pie chart and the line chart differ significantly from each other. Students of the experimental group have similar success levels in interpreting the bar chart and the pie chart. But they are significantly more unsuccessful in analysing a line chart than both a pie chart and a bar chart. Figure 2 shows chart analysis skill scores.

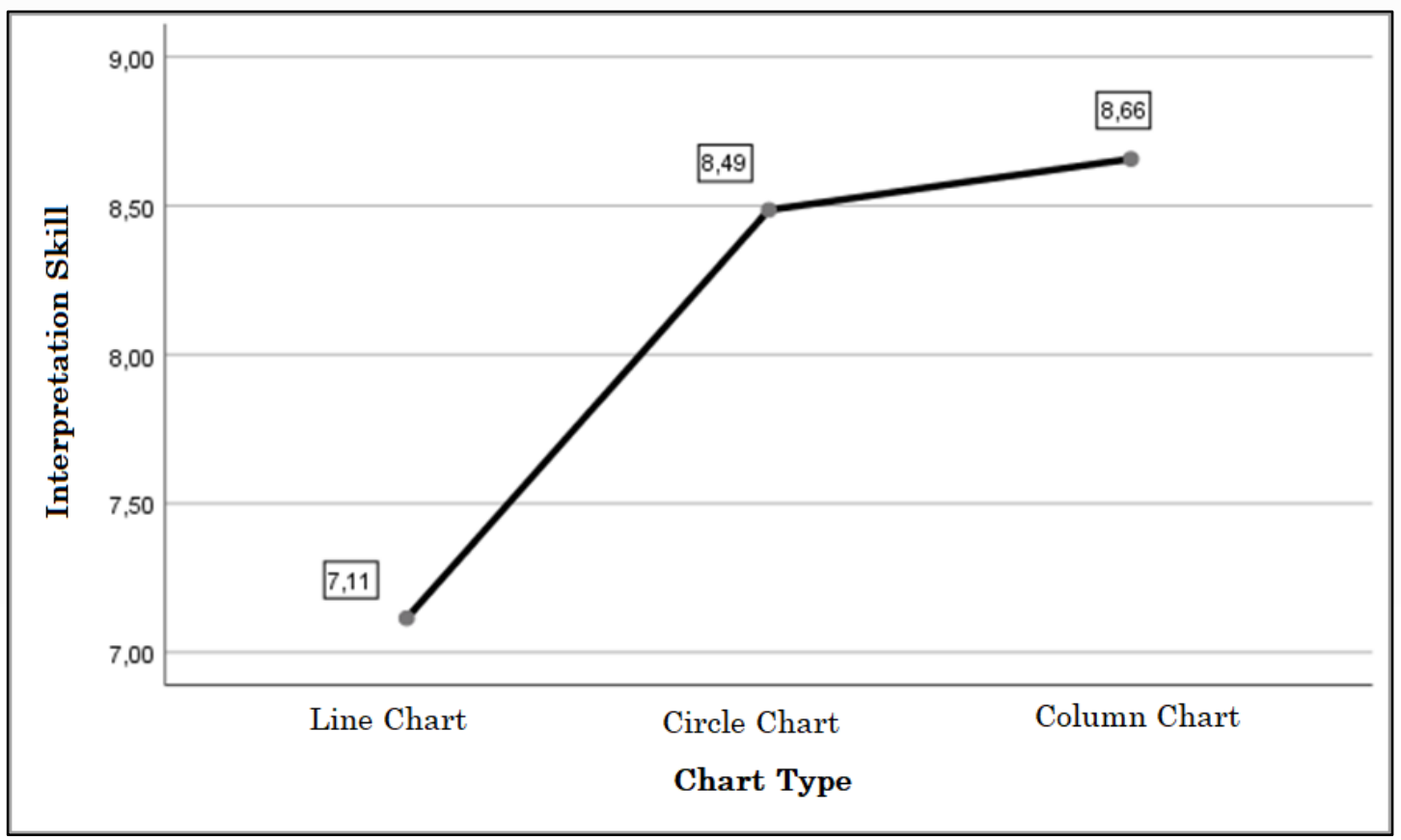

Figure 2. Comparison of chart analysis skill scores by chart type

\section{Findings about the Third Sub-Problem}

In the third sub-problem of the study, it is investigated whether the skill scores of experimental group students for drawing and interpreting charts differ according to the chart type variable. It was examined by variance analysis (ANOVA), which type of chart students were more successful in when their chart drawing and analysis skills were evaluated together, and whether their total skill scores differ 
Namal, R. (2021). Examination of the skills of secondary school students to draw and analysis graphs..

significantly from each other depending on the type of chart. The findings are shown in Table 7.

Table 7

Comparison of Chart Drawing Skill Scores by Chart Types

\begin{tabular}{|c|c|c|c|c|c|c|c|c|c|}
\hline $\begin{array}{l}\text { Skill to draw and } \\
\text { literacy (Total) }\end{array}$ & $\mathbf{n}$ & $\overline{\mathbf{x}}$ & Ss & Variance & $\begin{array}{c}\text { Sum of } \\
\text { Squares }\end{array}$ & Sd & $\begin{array}{l}\text { Squares } \\
\text { Average }\end{array}$ & $\mathbf{F}$ & $\mathbf{p}$ \\
\hline Line Chart & 35 & 20,71 & 2,14 & Intergroups & 307,200 & 2 & 153,600 & 34,601 & 0,000 \\
\hline Pie Chart & 35 & 23,46 & 1,92 & Ingroups & 452,800 & 102 & 4,439 & & \\
\hline Bar Chart & 35 & 24,83 & 2,26 & Total & 760,000 & 104 & & & \\
\hline
\end{tabular}

According to the results in Table 7, the most successful chart type was bar chart $=24.83$ according to the chart drawing and analysis score of the experimental group students, and the bar chart was followed by pie chart $=23.46$ and line chart $=20.71$, respectively. It was also found that there were significant differences between the total scores of chart drawing and analysis skills $(\mathrm{F}=34,601 ; \mathrm{p}<0.05)$. A Tukey HSD multiple comparison test (post hoc) was performed to determine which types of charts have significant differences. The findings are shown in Table 8.

Table 8

Multiple Comparison (Post Hoc) Findings on Comparing Chart Drawing and Analysis Skill Scores by Chart Type

\begin{tabular}{cccc}
\hline (A) Chart Type & (B) Chart Type & Difference between averages (A-B) & $\mathrm{p}$ \\
\hline \multirow{2}{*}{ Line Chart } & Pie Chart & $-2,74$ & 0,000 \\
\cline { 2 - 4 } & Bar Chart & $-4,11$ & 0,000 \\
\hline \multirow{2}{*}{ Pie Chart } & Line Chart & 2,74 & 0,000 \\
\cline { 2 - 4 } & Bar Chart & $-1,37$ & 0,021 \\
\hline \multirow{2}{*}{ Bar Chart } & Line Chart & 4,11 & 0,000 \\
\cline { 2 - 4 } & Pie Chart & 1,37 & 0,021 \\
\hline
\end{tabular}

According to the findings in Table 8, the total skill scores among all chart types differ significantly from each other. Students of the experimental group are significantly more successful in drawing and analysing a bar chart in general total than in drawing and analysing a pie chart and a line chart. They are also significantly more successful in drawing and interpreting a pie chart than in drawing and analysing a line chart. Hence students; considering the total scores, they are significantly more unsuccessful in drawing and interpreting a line chart than in drawing and interpreting both a pie chart and a bar chart. Figure 3 shows the skill scores for drawing and analysing charts. 


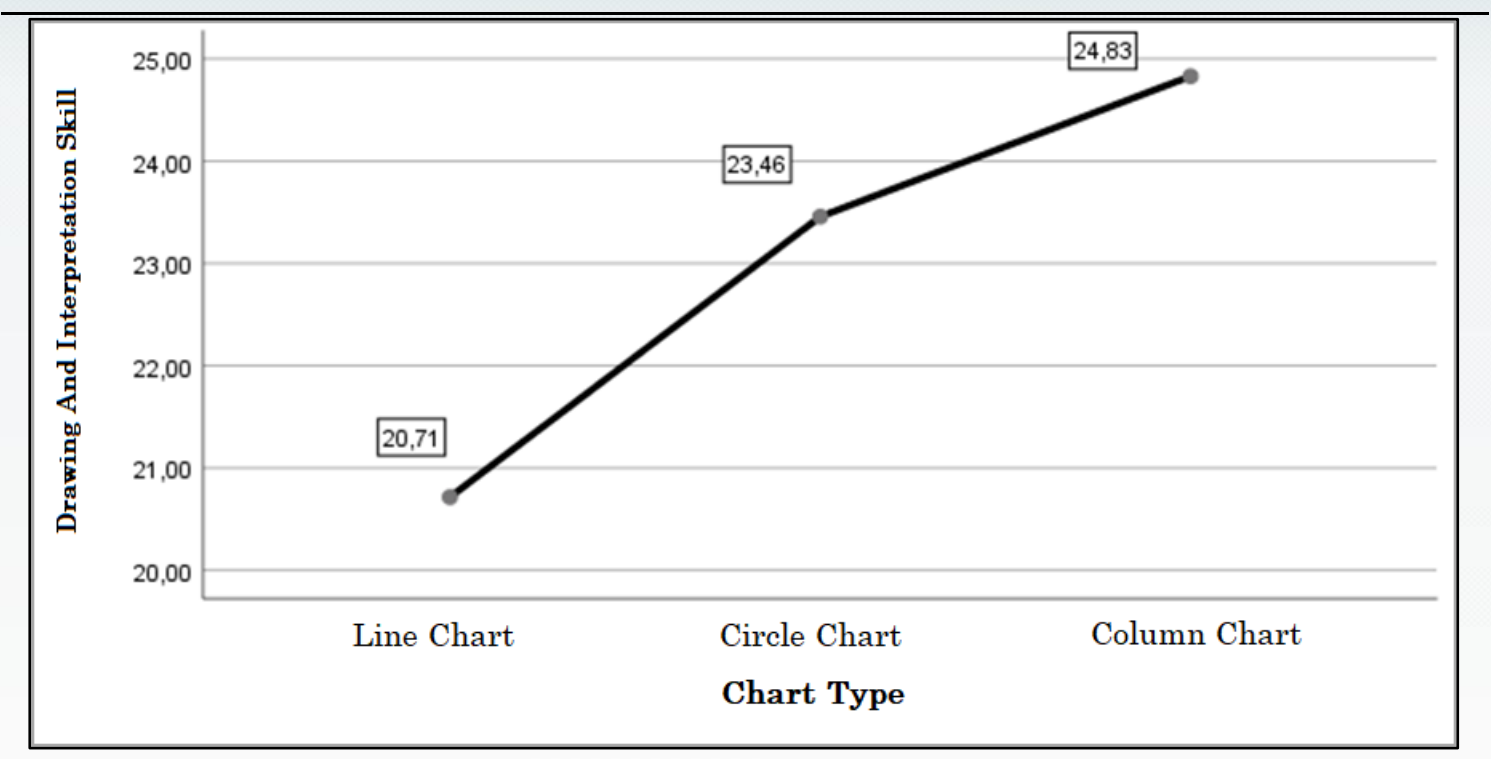

Figure 3. Comparison of chart drawing and analysis skill scores by chart type

\section{Findings about the Fourth Sub-Problem}

In the fourth sub-problem of the study, it is investigated whether the skill scores of the students of the experimental group differ according to the drawing and analysis variables. In order to enable comparison, the average scores of the students of the experimental group were calculated and the average scores of the students of the experimental group were calculated and The associated samples were examined with the t-test. The findings are shown in Table 9.

Table 9

Comparison of Chart Drawing and Analysis Skill Scores According To Drawing and Analysis Variables

\begin{tabular}{lcccllll}
\hline & $\mathrm{n}$ & $\overline{\mathbf{x}}$ & $\mathrm{Ss}$ & $\begin{array}{l}\text { Difference } \\
\text { between } \\
\text { averages }\end{array}$ & $\mathrm{t}$ & $\mathrm{Sd}$ & $\mathrm{p}$ \\
\hline Skill to draw & 105 & 1,49 & 0,19 & & & & \\
\hline Skill to Analysis & 105 & 1,35 & 0,27 & 0,14 & 5,116 & 104 & 0,000 \\
\hline
\end{tabular}

According to the results in Table 9, it was found that the average chart drawing skill score of experimental group students was $=1.49$ higher than the average chart analysis skill score of $=1.35$, and the difference of 0.14 points between skills was significant in favor of drawing skill $(\mathrm{t}=5,116$; $\mathrm{p}<0.05)$. Experimental group students are significantly more successful in chart analysis than in chart drawing. Figure 4 shows the average scores for drawing and analysing skills. 
Namal, R. (2021). Examination of the skills of secondary school students to draw and analysis graphs..

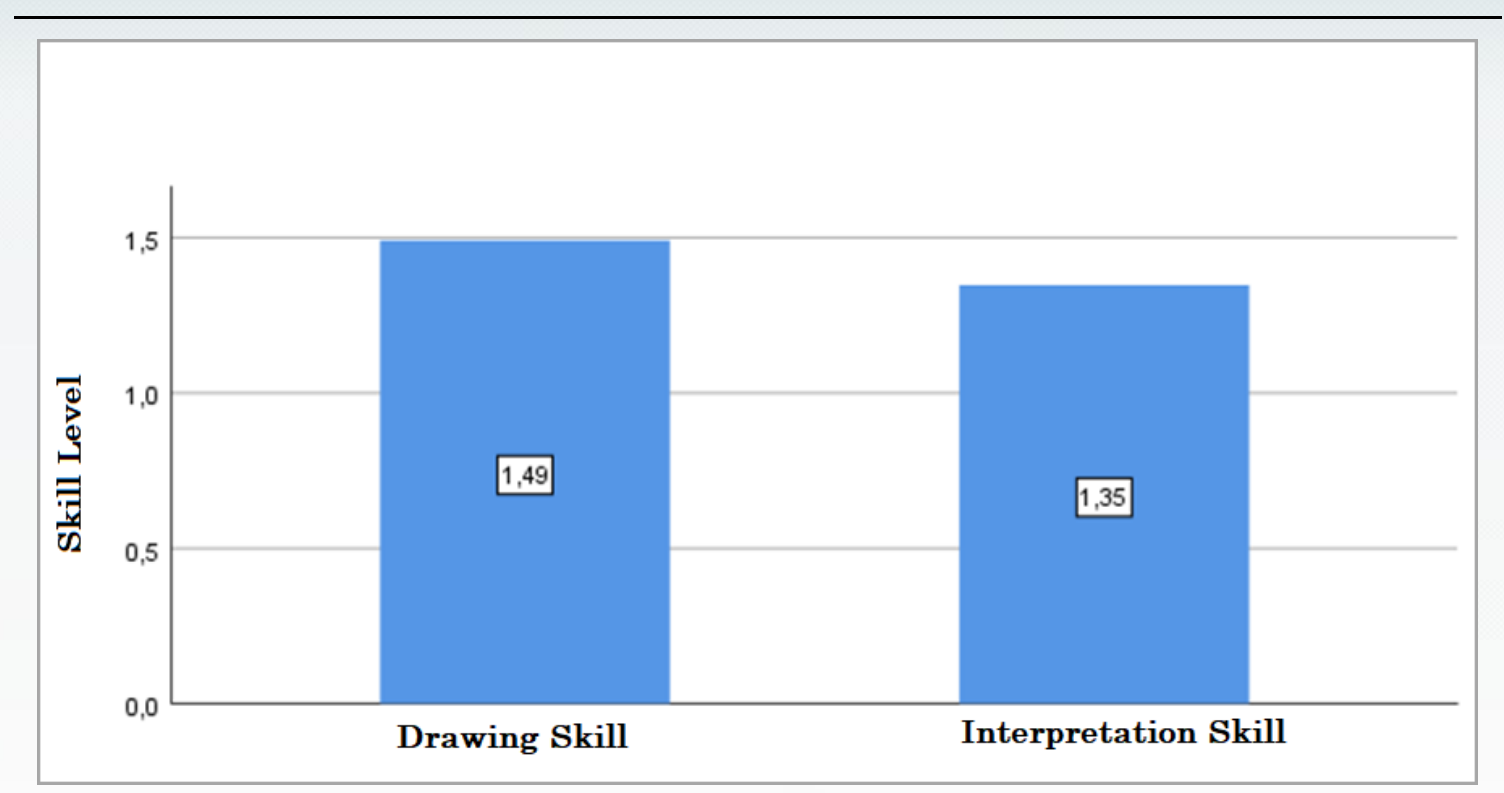

Figure 4. Comparison of chart drawing and analysis skill scores according to drawing and analysis variables

\section{Descriptive Findings Related to Measurement Results}

A total of 35 students were included in this study, which was conducted to examine the skills of secondary school students to draw and analysis line charts, pie charts, and bar charts. Table 10 shows descriptive findings about the skill to draw charts, the skill to analysis, and the overall skill total scores.

Table 10

Descriptive findings about skill to draw, skill to analysis, and general skill scores in all chart types

\begin{tabular}{ccccccc}
\hline Skill & n & Min. & Max. & $\overline{\mathbf{x}}$ & Ss & \%* \\
\hline Draw a line chart & 35 & 11,00 & 16,00 & 13,60 & 1,31 & 68,0 \\
\hline Line chart analysis & 35 & 4,00 & 10,00 & 7,11 & 1,41 & 59,3 \\
\hline Drawing and analysing a line chart & 35 & 16,00 & 26,00 & 20,71 & 2,14 & 64,7 \\
\hline Draw a pie chart & 35 & 12,00 & 18,00 & 14,97 & 1,64 & 74,9 \\
\hline Pie chart analysis & 35 & 6,00 & 11,00 & 8,49 & 1,42 & 70,8 \\
\hline Drawing and analysing a pie chart & 35 & 19,00 & 27,00 & 23,46 & 1,92 & 73,3 \\
\hline Draw a bar chart & 35 & 13,00 & 20,00 & 16,17 & 1,65 & 80,9 \\
\hline Bar chart analysis & 35 & 5,00 & 11,00 & 8,66 & 1,51 & 72,2 \\
\hline Drawing and analysing a bar chart & 35 & 19,00 & 29,00 & 24,83 & 2,26 & 77,6 \\
\hline
\end{tabular}

* It is rated the lowest and highest score that can be received.

According to the results in Table 10, the skill to draw a line chart was found to be the total average score $=13.60$; the skill to analysis a line chart was the total average score $=7.11$; the skill to draw and analysis a line chart (general) was found to be the 
total average score $=20.71$. Skill to draw a pie chart total average score $=14.97$; skill to analysis a pie chart total average score $=8.49$, and skill to draw and analysis a pie chart (General) total average score $=23.46$. Finally, skill to draw a bar chart total average score $=16.17$; skill to analysis a bar chart the total average score $=8.66$ and the skill to draw and analysis a bar chart was found to be a total average score $=24.83$. As a result of the ratio of these scores to the lowest and highest scores that can be obtained from the tests, the skill with which students were most successful was the skill to draw a bar chart with $80.9 \%$. This was followed by drawing and in analysing a bar chart (77.6\%); drawing a pie chart (74.9\%), drawing and analysing a pie chart (73.3\%), analysing a bar chart (72.2\%), analysing a pie chart $(70.8 \%)$, drawing a line chart (68\%), drawing and analysing a line chart (64.7\%), and analysing a line chart (59.3\%), respectively. From these results, it seems that the type of chart in which students are more difficult to draw and analysis than others is a line chart.

\section{Result and Discussion}

In this study, it was aimed to examine the skill of secondary school students to draw and analysis charts using the bar chart, pie chart and line chart, known as the three basic chart types in Social Studies teaching. Accordingly, a research process was carried out in the one-group post-test model, which included activities based on the skill to draw and analysis charts. In the study, whether the drawing and analysis skill scores of experimental group students differ according to the drawing variable, the analysis variable, and the chart type variable; answers were searched for whether chart drawing skill scores and chart analysis skill scores differed according to the chart type variable.

In the results obtained from the study, the effect of the drawing variable, analysis variable and chart type variable on the skill scores to draw and interpret charts was significant. According to the results obtained from the sub-problems of the study, it seems that the type of chart in which students of the experimental group are most successful in drawing and analysing charts is a bar chart. A pie chart that has very close values to a bar chart is another type of chart that students succeed in drawing and analysing. In the studies conducted by Schield (2006), Beler (2009), Akgün (2010) and Namal (2019), students' skill to draw and analysis the bar chart and pie chart is high and close to the results of the research in this aspect.

The findings from the research results, the study skills students in the experimental group is more successful than the skill to analysis chart data chart, and a type of the most difficult to analysis chart is a line chart. Similar to the research results, Wainer (1980), Kwon (2002), Yayla \& Özsevgeç (2014) and Namal (2019)'s research as their weakest students the skill to analysis and draw the chart type to a line chart. 
Namal, R. (2021). Examination of the skills of secondary school students to draw and analysis graphs..

\section{Suggestions}

Depending on the data obtained from the research results, the following recommendations are made:

- It is recommended to develop educational applications and measurement tools to improve the skill to draw and analysis line charts.

- Research is recommended to improve the skill to analysis charts.

- It is recommended that the GDAS-CL scale be used in research and teaching applications related to the study and development of the skill to draw and analysis charts.

- It is recommended to develop research and teaching practices aimed at improving the skill to draw and analysis charts.

\section{References}

Açıkalın, M. (2017). Araştırmaya dayalı sosyal bilgiler öğretimi. Ankara: Pegem.

Akgün, İ. H. (2010). The acquisition level of the students studying social sciences of abilities to interpret and prepare graphics (Master thesis), Retrieved from https://tez.yok.gov.tr/UlusalTezMerkezi/tezSorguSonucYeni.

Anıl, D., Özer Özkan, Y., \& Demir, E. (2015). PISA 2012 araştırması ulusal nihai rapor. Ankara: İşkur Matbaacilık.

Anscombe, F. J. (1973). Graphs in statistical analysis. The american statistician, 27(1), 17-21.

Arıkan, R. (2003). Grafikler. Ankara: Pegem.

Beattie, V., \& Jones, M. J. (2002). Measurement distortion of graphs in corporate reports: an experimental study. Accounting, Auditing \& Accountability Journal, 15(4), 546-564.

Beler, Ş. (2009). Determining 8th grade students' difficulties in reading and interpreting graphs of photosynthesis subject (Matser thesis). Retrieved from https://tez.yok.gov.tr/UlusalTezMerkezi/tezSorguSonuc

Curcio, F. R. (1987). Comprehension of mathematical relationships expressed in graphs. Journal for research in mathematics education, 382-393.

Davison, B. K. (2013). Universal graph literacy: understanding how blind and low vision studentscan satisfy the common core standarts with accessible audority graphs, (Doctoral dissertation). George Instute of Technology.

Dilek, M., İşçi, Ö. \& Göktaş, A. (2010). Uygulamalı İstatistik. Muğla: Muğla Üniveristesi Yayınları.

Duplass, J. A. (1996). Charts, tables, graphs, and diagrams: An approach for social studies teachers. The Social Studies, 87(1), 32-38.

Friel, S. N., \& Bright, G. W. (1996). Building a Theory of Graphicacy: How Do Students Read Graphs?. Retrieved from https://files.eric.ed.gov/fulltext/ED395277.pdf

Fry, E. (1981). Graphical literacy. Journal of Reading, 24(5), 383-389.

Güler, H. K. (2013). Analysis of Turkish Students' Difficulties Encountered in PISA, Uludăg Üniversitesi Ĕ̈itim Fakültesi Dergisi, 26(2), 501-522.

Karasar, N. (2004). Bilimsel Araştırma Yöntemi. Ankara: Nobel Yayın Dağıtım. 
Korol, J. K. (1986). Graphical perception and the representation of financial information. Georgia Journal of Accounting, 7(spring), 147-157.

Kwon, O. N. (2002). The effect of calculator-based ranger activities on students' graphing ability. School Science and Mathematics, 102(2), 57-67.

Lawshe, C. H. (1975). A quantitative approach to content validity. Personnel psychology, 28(4), 563-575.

Leivian, G. M. (1980). How to communicate financial data more efficiently. Management Accounting, 62(1), 31-34.

Manhood, W., Biemer, L. \& Lowe, W. T. (1991). Teaching social studies in middle and senior high schools. New York: Macmillan Publishing Co.

Martin, M. O., Mullis, I. V., Foy, P. \& Stanco, G. M. (2011). International results in science. Amsterdam: IAEEA.

MEB. (2005). İlköğretim sosyal bilgiler dersi (4-5. sınıflar) öğretim programı ve kılavuzu. Ankara: Devlet Kitapları Basımevi.

MEB. (2018). Sosyal bilgiler dersi öğretim programı 4,5,6 ve 7. sınıflar. Ankara: MEB.

Namal, R. (2019/a). Tablo, grafik ve diyagram çizme ve yorumlama. B. Aksoy, B. Akbaba \& B. Kılcan (Ed). In Sosyal bilgilerde beceri eğitimi (s. 517-535). Ankara: Pegem.

Namal, R. (2019/b). The development of graph drawing ang interpretation skills in social studies teaching (Ph.D. Thesis). Gazi Üniversitesi Eğitim Bilimleri Enstitüsü.

Oruç, Ş., \& Akgün, İ. H. (2010). The acquisition level of graphic reading skills of elementary social studies 7th grada students. Uluslararası Avrasya Sosyal Bilimler Dergisi, 1(1), 51-58.

Öztürk, C. (Ed.). (2012). Sosyal bilgiler öğretimi. Ankara: Pegem.

Parker, W. (2001). Social Studies in Elementary Education, 14/e. Pearson Education India.

Savage, T. V., \& Armstrong, D. G. (1996). Effective Teaching in Elementary Social Studies (6th edition), PrenticeHaII Publication.

Schield, M. (2006). Statistical literacy survey analysis: Reading graphs and tables of rates and percentages. In Proceedings of the Sixth International Conference on Teaching Statistics. Ciudad del Cabo: International Statistical Institute and International Association for Statistical Education.

Sofo, F. (1985). Graphic literacy: Part I. A review of the literature. The Vocational Aspect of Education, 37(98), 107-113.

Taş, U. E., Arıcı, Ö., Özarkan, H. B. \& Özgürlük, B. (2016). PISA 2015 ulusal nihai raporu. Ankara: Milli Eğitim Bakanlığı.

Ulusoy, K., \& Gülüm, K. (2009). To use of teachers to the teaching materials while studying history and geography subjects in social science lessons. Journal of Kirsehir Education Faculty, 10(2).

Veneziano L. \& Hooper J. (1997). A method for quantifying content validity of health-related questionnaires. American Journal of Health Behavior, 21 (1), 67-70.

Wainer, H. (1980). A test of graphicacy in children. Applied Psychological Measurement, 4(3), 331-340.

Wainer, H. (1992). Understanding graphs and tables. Educational researcher, 21(1), 14-23. 
Namal, R. (2021). Examination of the skills of secondary school students to draw and analysis graphs..

Wong, J. Y. Y., \& Gerber, R. (1997). Singapore students' perceptions of graphs, charts and maps. Asia Pacific Journal of Education, 17(2), 63-76.

Yayla, G. \& ÖzsevgeçT. (2015). The Examination Of Secondary School Students' Graphic Skills: Construction And Interpretation of Line Graphs. Kastamonu Eğitim Dergisi, 23(3), 1381-1400.

Yazici, K. (2006). Sosyal bilgilerde kullanılan görsel araçlar: haritalar-küreler, resimler, tablolar ve grafikler. Selçuk Üniversitesi Sosyal Bilimler Enstitüsü Dergisi, (15), 651662.

Yurdugül, H. (2005). Ölçek geliştirme çalışmalarında kapsam geçerliği için kapsam geçerlik indekslerinin kullanılması. XIV. Ulusal Eğitim Bilimleri Kongresi, 1, 771-774.

\section{Biographical Statement}

Remzi NAMAL Remzi Namal completed his PhD in Social Studies Education at Gazi University Institute of Educational Sciences. He serves in the Ministry of education in Düzce province. His fields of study are social studies education and geographical education.

Appendix

Chart Drawing and Analysis Skill Checklist (GDAS-CL) Scale

\begin{tabular}{|c|c|c|c|c|}
\hline & & $\begin{array}{l}\text { Yes } \\
(2)\end{array}$ & $\begin{array}{l}\text { Maybe } \\
\text { (1) }\end{array}$ & $\begin{array}{l}\text { No } \\
(0)\end{array}$ \\
\hline 1 & It uses suitable material for chart drawing. & & & \\
\hline 2 & Recognizes the components of the chart (axis, circle). & & & \\
\hline 3 & $\begin{array}{l}\text { Determine the type of chart to be drawn using the } \\
\text { presented data. }\end{array}$ & & & \\
\hline 4 & $\begin{array}{l}\text { It follows the correct stages depending on the type of } \\
\text { chart in the chart drawing. }\end{array}$ & & & \\
\hline 5 & $\begin{array}{l}\text { It can write data to the corresponding sections } \\
\text { (horizontal and vertical axes, slices) in the chart. }\end{array}$ & & & \\
\hline 6 & It can write units or values of data in the correct place. & & & \\
\hline 7 & $\begin{array}{l}\text { It can make applicable measurements to write the } \\
\text { data correctly. }\end{array}$ & & & \\
\hline 8 & $\begin{array}{l}\text { It can draw according to the appropriate rank width } \\
\text { and proportions. }\end{array}$ & & & \\
\hline 9 & Draw the desired chart using the data. & & & \\
\hline 10 & It can draw a chart in another appropriate chart type. & & & \\
\hline 11 & It can write a title according to the content of the chart. & & & \\
\hline 12 & $\begin{array}{l}\text { Explain numerical data related to the chart with } \\
\text { simple expressions. }\end{array}$ & & & \\
\hline 13 & It can be inferred from the data in the chart. & & & \\
\hline 14 & It can make predictions based on the data in the chart. & & & \\
\hline 15 & $\begin{array}{l}\text { Explain the relationship between designs by analysing } \\
\text { the chart. }\end{array}$ & & & \\
\hline 16 & $\begin{array}{l}\text { It can make quantitative/proportional comparison } \\
\text { between the same or different types of charts. }\end{array}$ & & & \\
\hline
\end{tabular}

